\title{
The False Charge - A Form of Violence?
}

\author{
Elżbieta Loska
}

University of Cardinal Stefan Wyszyński, Warsaw

Kontaktnie-mail:e.loska@uksw.edu.pl

\begin{abstract}
:
Laws in ancient Rome concerning the use of vis stated what was considered violence and how it was penalized. The most interesting among them were the lex Cornelia de sicariis et veneficis and two Augustan laws: the lex Iulia de vi publica and the lex Iulia de vi privata. They allow to assume that violence was possible also during the trial, and not only as a physical emanation of force.
\end{abstract}

Keywords: Roman law; criminal trial; vis

DOI: $10.14712 / 2464689 X .2020 .4$

To present my point of view, first I must make a few rather obvious remarks.

The concept of vis in the Roman world was not uniform. ${ }^{1}$ The word vis itself had most probably a neutral connotation for a long time - it should be translated as "force", not as "violence". 2 The Oxford Latin Dictionary ${ }^{3}$ gives us 28 meanings of the word. Among them are: strength, force, meaning, significance, value, influence, power, and, of course, violence. It is difficult to determine exactly when the use of the word vis came to be associated unambiguously negatively. The moment of introducing legislation directed against violence (contra vim) might be some suggestion. In this context the word vis undoubtedly meant violence used illegally.

\section{Legislation against violence}

Criminal legislation against the use of vis ${ }^{4}$ appeared in Roman law ${ }^{5}$ relatively late. Solutions exploiting some kind of force seemed till that date (and even afterwards) acceptable

1 Cf. COSSA, G. Attorno ad alcuni aspetti della lex Iulia de vi publica e privata. Roma, 2007, p. 1, and bibliography there presented.

2 SOLIDORO MARUOTTI, L. La repressione della violenza nel diritto romano. Napoli: Jovene, 1993, p. 11; LINTOTT, A. W. Violence in Republican Rome. Oxford: Oxford University Press, 1999, p. 22.

3 OLD, s.v. vis.

$4 \quad$ About vis see: LONGO, G. S.v. vis. In: Novissimo Digesto Italiano (NNDI), 1975, 20, p. 989 ff.; MAYERMALY, Th., s.v. Vis, Vis als Selbsthilfe. RE 9a/1961, col. $315 \mathrm{ff}$.

5 On legislation against violence see LINTOTT, Violence in Republican Rome, p. 107 ff. 
in many areas of life. Those were applied, for example, during the political struggle, ${ }^{6}$ but also to exert pressure on the unwilling party of a private law contract. For the Romans it was a daily, ordinary, suitable way of dealing with any kind of enemy, with the political chaos of the times of the fall of the Republic only fuelling it. Perhaps it was the escalation that made it necessary to counteract the abuse of the force, meaning the use of violence. Thus, some behaviours began to be penalized.

The first regulation in this area seems to be the lex Lutatia, ${ }^{7}$ issued probably in $78 \mathrm{BC} .{ }^{8}$ It is possible, however, that this act was accepted earlier, already in $102 \mathrm{BC}$, because of the riots related to the choice of censors and trouble with one of the plebeian tribunes, Saturninus. ${ }^{9}$ Another law passed to fight the use of violence was the lex Plautia de $v i^{10}$ of 65 or $64 \mathrm{BC}$. The lex Pompeia de vil1 was the reaction to the incident on the via Appia in $52 \mathrm{BC}$, when Clodius was murdered by Milo's people. The next regulation were the leges Iuliae de vi publica et privata ${ }^{12}$ from the times of Julius Ceasar ${ }^{13}$ or Octavian August. ${ }^{14} \mathrm{It}$ is likely that the regulations against violence were initiated by both Caesars - Julius Caesar was a designer (rogator) of the lex Iulia de $v i^{15}$ (passed in $46 \mathrm{BC}$ ), and Octavian led to the implementation of the laws known to us from the comments in the Justinian codification. ${ }^{16}$ The bill or bills resulting from Augustus' proposal probably came from the period between

6 Cf. LABRUNA, L. Iuri maxime... adversaria. La violenza tra reppresione privata e persecuzione pubblica nei conflitti politici della tarda repubblica. In: MILAZZO, F. (ed.). Illecito e pena privata in età repubblicana. Atti del convegno internazionale di diritto romano, Copanello 4-7 giugno 1990. Napoli: Edizioni Scientifiche Italiane, 1992, p. 255 ff.; KOWALSKI, H. Leges per vim contra auspicia latae. Religia, polityka i prawo karne w Rzymie. In: DĘBIŃSKI, A. - KOWALSKI, H. - KURYŁOWICZ, M. (ed.). Salus rei publicae suprema lex. Ochrona interesów państwa w prawie karnym starożytnej Grecji i Rzymu. Lublin: Wydawnictwo KUL, 2007, p. 104.

7 The existence of this act is evidenced by a fragment from Cicero's speech in defense of Caelius - Cic. Cael. 70: De vi quaeritis. Quae lex ad imperium, ad maiestatem, ad statum patriae, ad salutem omnium pertinet, quam legem Q. Catulus armata dissensione civium rei publicae paene extremis temporibus tulit, quaeque lex sedata illa flamma consulatus mei fumantes reliquias coniurationis exstinxit, hac nunc lege Caeli adulescentia non ad rei publicae poenas, sed ad mulieris libidines et delicias deposcitur?; see also HOUGH, J. N. The lex Lutatia and the lex Plautia de vi. American Journal of Philology, 1930, 51, 2, p. 141; BIENIEK, S. Geneza interdyktu de vi armata. Acta Universitatis Wratislaviensis 63, Prawo, 1967, 18, p. 20; LINTOTT, Violence in Republican Rome, p. 113 ff.; HARRIES, J. Law and Crime in the Roman World. Cambridge: Cambridge University Press, 2007, p. 107.

8 RIGGSBY, A. M. Crime and Community in Ciceronian Rome. Austin: University of Texas Press, 1999, p. 79.

9 Arguments in favour of this date convincingly shows KELLY, B. The Law that Catulus Passed. In: WELCH, K. - HILlARD, T. W. (eds.). Roman Crossings. Theory and Practice in the Roman Republic. Cambridge: Classical Press of Wales, 2005, p. $100 \mathrm{ff}$.

10 ROTONDI, G. Leges publicae populi Romani. Milano: Società editrice libraria, 1912, p. 377 ff.; HOUGH, op. cit., p. 146; HARRIES, Law and Crime in the Roman World, p. 107.

11 ROTONDI, op. cit., p. 410; HARRIES, Law and Crime in the Roman World, p. 107.

12 Cf. ROTONDI, op. cit., p. 450 ff., gives the date 17 BC; LONGO, G. S.v. Lex Iulia de vi publica e lex Iulia de vi privata. NNDI, 1963, 9, p. 812.

13 CLOUD, J. D. Lex Iulia de vi. In: CRAWFORD, M. (ed.). The Roman Statutes. London: Institute of Classical Studies, School of Advanced Study, University of London, 1996, p. $789 \mathrm{ff}$.

14 COSSA, op. cit., p. 79, along with the quoted literature.

15 Cf. Cic. Phil. 1, 9, 23: Quid, quod obrogatur legibus Caesaris, quae iubent ei, qui de vi, itemque ei, qui maiestatis damnatus sit, aqua et igni interdici? Cf. ROTONDI, op. cit., p. 422-423.

16 Cf. LINTOTT, Violence in Republican Rome, p. 107 ff. 
19 and 16 BC. ${ }^{17}$ The issue of the admissibility of using the vis was also to some extent addressed in the lex Cornelia de sicariis et veneficis, ${ }^{18}$ from the times of Sulla in $81 \mathrm{BC}$.

Such a late appearance, and in quite a few regulations penalizing ${ }^{19}$ the abuse of vis seems significant. This proves what was suggested above - Roman citizens were not unfamiliar or disagreeable with resolving conflicts by force. ${ }^{20}$ Only when the abuse of this measure began to be a problem, it led to regulating the issue by the state. It was even believed that the desire to achieve a political (apparently, more important) goal could be a moral justification for the use of violence. ${ }^{21}$ The use of vis was also fully allowed when it came to self-defense. ${ }^{22}$ One can argue that not only the purpose of using vis, but also the place where violence took place is meaningful for its use being more or less acceptable. ${ }^{23}$

\section{The rhetorical approach}

Let me focus on the significance of vis at the end of the Republic and the beginning of the Principate - exactly when the implication of the word appears to have changed. The use of the word vis in court speeches was a good example of it.

If we speak of the meaning of language, the works of the master of words, Cicero, must be taken into consideration. There is one speech which seems very important for the development of the connotations of vis. It is Pro Sestio.

Publius Sestius was a plebeian tribune in 57 BC (he shared this office, among others, with Milo). In this year, which was not unusual at that time, Rome was ruled by armed bands fighting with each other. The most important opposing gangs were headed by Titus Annius Milo and Publius Clodius Pulcher. Those armed gangs in Cicero’s time were used

17 Cf. CLOUD, Lex Iulia de vi, p. 789.

18 ROTONDI, op. cit., p. 357 ff.; see i.a. CLOUD, J. D. The Primary Purpose of the lex Cornelia de sicariis. ZSS, 1969, 86, passim; SANTALUCIA, B. S.v. Silla. NNDI, 1970, 17, s. 345; NÖRR, D. Causa mortis. München: Beck, 1986, p. 86 ff.; FERRARY, J.-L. Lex Cornelia de sicariis et veneficis. Athenaeum, 1991, 79, passim; Idem. Lex Cornelia de sicariis et veneficis. In: CRAWFORD, M. (ed.). The Roman Statutes. London: Institute of Classical Studies, School of Advanced Study, University of London, 1996, p. 749-753; SANTALUCIA, B. Studi di diritto penale romano. Roma: L'Erma di Bretschneider, 1994, p. 118 ff.; AMIELAŃCZYK, K. Lex Cornelia de sicariis et veneficis. Annales UMCS, 1996, 43, p. 281 ff.; Idem. Twórcza interpretacja legis Corneliae de sicariis et veneficis przez Hadriana i jurysprudencję cesarską. Studia Prawnoustrojowe, 2007, 7, p. 24; HARRIES, Law and Crime in the Roman World, p. 106.

19 On the issue of criminal legislation de vi concerning piracy, see TARWACKA, A. Romans and Pirates: Legal Perspective. Warszawa: Wydawnictwo Uniwersytetu Kardynała Stefana Wyszyńskiego, 2009, p. $101 \mathrm{ff}$.

20 Cf. GRUEN, E. S. The Last Generation of the Roman Republic. Berkeley - Los Angeles - London: University of California Press, 1995, p. 433. The author writes that violence was inscribed in Roman history, and moreover popular justice and self-help also found their place in the legal structure. Also: HARRIES, Law and Crime in the Roman World, p. 106 - she even writes, that violence was endemic to the Roman culture.

21 LINTOTT, Violence in Republican Rome, p. 52. See also LENSKI, N. Violence and Roman Slave. In: RIESS, W. - FAGAN, G. G. (eds.). The Topography of Violence in the Graeco-Roman World. Ann Arbor: University of Michigan Press, 2016, p. 285.

22 I.a. Cic. pro Mil. 9-11; D. 1, 1, 3; D. 9, 2, 4pr.; D. 43, 16, 1, 27; D. 43, 16, 3, 9. See HARRIES, Law and Crime in the Roman World, p. 116; LOSKA, E. Zagadnienie obrony koniecznej w rzymskim prawie karnym. Warszawa: Wydawnictwo Uniwersytetu Kardynała Stefana Wyszyńskiego, 2011, passim with the bibliography.

23 FAGAN, G. G. Urban Violence: Street, Forum, Bath, Circus and Theater. In: RIESS, W. - FAGAN, G. G. (eds.). The Topography of Violence in the Graeco-Roman World. Ann Arbor: University of Michigan Press, 2016, p. 232. 
also to help political agitation. ${ }^{24}$ This made them a normal sight on the streets of Rome. Sestius started to use armed security after the incident that could end in his death.

Sestius was charged with electoral crimes (de ambitu) and de vi. The second charge was based on hiring armed men by Sestius for his own security - they also took part in the riots. The trial began on February 10, $56 \mathrm{BC}$, and ended on March 11 of the same year. ${ }^{25} \mathrm{As}$ already said, Sestius was defended by one of the most prominent orators in Rome, Marcus Tullius Cicero. The reason for this was simple: Sestius was one of the people who fought for the orator's return from exile. ${ }^{26}$ The prosecutors were P. Albinovanus and T. Claudius. ${ }^{27}$ Apart from Cicero, Sestius was defended by distinguished representatives of the Roman nobilitas: Marcus Licinius Crassus, Licinius Calvus and Quintus Hortensius Hortalus. ${ }^{28}$

The beginning of Cicero's speech was devoted to describing and praising the character of Sestius. Then he proceeded to describe the shocking condition of the state in the year of Sestius' tribunate. ${ }^{29} \mathrm{He}$ reminded the court about the damage made by Clodius acting as a tribune of the plebs in the previous year that affected politics in $57 \mathrm{BC}$. He was the rogator of many destructive plebiscita: e.g. from his instigation the censor's note being abolished, ${ }^{30}$

24 EBERT, U. Die Geschichte des Edikts de hominibus armatis coactisve. Heidelberg: Carl Winter Universitätsverlag, 1968, p. 11.

25 On the trial of Sestius see i.a. GRUEN, op. cit., p. 300 ff.; VITZTHUM, W. Untersuchungen zum materielen Inhalt der lex Plautia und lex Iulia de vi. München: Dissertations-Druckerei C. Schön, 1966, p. 17 ff.; RIZZO, S. Introduction to Cicerone. Due scandali politici: Pro Murena, Pro Sestio. Milano: BUR Biblioteca Univ. Rizzoli, 1988, p. 195; CRAIG, Ch. Shifting Charge and Shifty Argument in Cicero's Speech for Sestius. In: WOOTEN, C. W. - KENNEDY, G. The Orator in Action and Theory in Greece and Rome: Essays in Honor of George A. Kennedy. Leiden: Brill, 2001, p. 112 ff.; ALEXANDER, M. C. Trials in the Late Roman Republic. 149 BC to 50 BC. Toronto: University of Toronto Press, 1990, p. 131-132 (n. 270-271); Idem. The Case for the Prosecution in the Ciceronian Era. Ann Arbor: University of Michigan Press, 2002, p. 206 ff.; cfr. also SALERNO, F. Quantum intersit inter populum Romanum et contionem. Cicerone e la contio nella Pro Sestio. In: Fides, humanitas, ius. Studii in onore di Luigi Labruna, VII. Napoli: Editoriale scientifica, 2007, p. 4937

26 WOOD, N. Cicero's Social and Political Thought. Berkeley - Los Angeles - London: University of California Press, 1988, s. 62.

27 ALEXANDER, Case for the Prosecution in the Ciceronian Era, p. 207. It is very likely that the prosecutors acted on the orders of Clodius, given they were assisted by Publius Vatinius, the legate of Julius Caesar-Sch. Bob. Pro Sestio argumentum, p. 82, 22-27. Clodius did not like Sestius, since the latter contributed to Cicero's return to Rome. Of personal dislike as a reason for making accusations: EPSTEIN, D. F. Personal enmity in Roman politics, 218-43 B.C. New York: Routledge Kegan \& Paul, 1987, p. 102; GRUEN, op. cit., p. 272;

28 Sch. Bob. Pro Sestio argumentum, p. 83, 9-10.

29 Cic. Sest. 55: Sed ut a mea causa iam recedam, reliquas illius anni pestis recordamini-sic enim facillime perspicietis quantam vim omnium remediorum a magistratibus proximis res publica desiderarit - legum multitudinem, cum earum quae latae sunt, tum vero quae promulgatae fuerunt. nam latae quidem sunt consulibus illis tacentibus dicam? immo vero etiam adprobantibus; ut censoria notio et gravissimum iudicium sanctissimi magistratus de re publica tolleretur, ut conlegia non modo illa vetera contra senatus consultum restituerentur, sed (ab) uno gladiatore innumerabilia alia nova conscriberentur.

30 In fact, as is known from the passage of Commentaries by Asconius Pedianus lex Clodia de censoria notione, (ROTONDI, op. cit., p. 398), limited the use of the censor note without abolishing it. See Asc. in Pis. 8 C: Diximus L. Pisone A. Gabinio coss. P. Clodium tr.pl. quattuor leges perniciosas populo Romano tulisse: annonariam, de qua Cicero mentionem hoc loco non facit - fuit enim summe popularis - ut frumentum populo quod antea senis aeris trientibus in singulos modios dabatur gratis daretur: alteram ne quis per eos dies quibus cum populo agi liceret de caelo servaret; propter quam rogationem ait legem Aeliam et Fufiam, propugnacula et muros tranquillitatis atque otii, eversam esse; - obnuntiatio enim qua perniciosis legibus 
the collegia (abolished by the Senatusconsultum in $64 \mathrm{BC}$ ) were restored. ${ }^{31}$ According to the orator, all actions taken by Sestius were to protect the state against any further harmful activities of his predecessor in the office.

Of particular interest in this passage is the remark made by Cicero, intended to show the judges that the situation, in which the Roman state found itself in the year of Sestius' tribunate, was not fortunate. Therefore, all elected officials, Sestius included, should have used all possible means to save the Republic. ${ }^{32}$ The expression vim omnium remediorum should be treated as ambiguous - the word vis in addition to its metaphorical meaning in this sentence, could also have the direct sense and signify simply strength, indicating the measure that should be applied to avoid the total disaster. ${ }^{33}$

In the light of this passage the strategy of defence, applied by Cicero, seems clear. The orator defended the accused, claiming that all measures taken by Sestius were used in the interests of the state. He did not say clearly that it was Sestius who used vis, but admitted that the vis was used. ${ }^{34} \mathrm{He}$ did not deny that during his term in office Sestius surrounded himself with armed men, because it would be difficult to deny it, but he emphasized the intentions of the former tribune. ${ }^{35}$ Sestius' behaviour was justified and in the public interest, contrary to the violence used by Clodius. ${ }^{36}$ Therefore, the actions of Sestius should be considered legal.

Cicero devoted part of the speech to the description of the atrocities committed by Clodius, who was not in office at that time. ${ }^{37}$ Among other things, he prepared the riots

resistebatur, quam Aelia lex confirmaverat, erat sublata - : tertiam de collegiis restituendis novisque instituendis, quae ait ex servitiorum faece constituta: quartam ne quem censores in senatu legendo praeterirent, neve qua ignominia afficerent, nisi qui apud eos accusatus et utriusque censoris sententia damnatus esset. Cf. also Sch. Bob. Pro Sestio argumentum, p. 93, 13-16, and LINTOTT, A. The Constitution of the Roman Republic. Oxford: Oxford University Press, 2004, p. 120.

$31 \quad$ Lex Clodia de collegiis - ROTONDI, op. cit., p. 393.

32 Similar arguments also appeared in the later part of the speech, however, it concerned the person of Milo, Sestius' colleague in the office - Cic. Sest. 86: Si leges non valerent, iudicia non essent, si res publica vi consensuque audacium armis oppressa teneretur, praesidio et copiis defendi vitam et libertatem necesse esse. In the next passage, Cicero summons the opinion of the Sestius' prosecutor, who praised Milo for hiring the armed men protecting his home against Clodius' gangs. It is possible that the action of Milo has been easily recognized as legitimate, because he acted in the self-defence - he protected his goods from assault, cf. ALEXANDER, The Case for the Prosecution in the Ciceronian Era, p. 214.

33 Cf. RIGGSBY, op. cit., p. 90.

34 Ibidem, s. 90.

35 Cic. Sest. 84: 'homines, 'inquit, 'emisti, coegisti, parasti.' quid uti faceret? senatum obsideret? civis indemnatos expelleret? bona diriperet? aedis incenderet? tecta disturbaret? templa deorum immortalium inflammaret? tribunos plebis ferro e rostris expelleret? provincias quas vellet quibus vellet venderet? reges appellaret? rerum capitalium condemnatos in liberas civitates per legatos nostros reduceret? principem civitatis ferro obsessum teneret? haec ut efficere posset, quae fieri nisi armis oppressa re publica nullo modo poterant, idcirco, credo, manum sibi P. Sestius et copias comparavit. 'at nondum erat maturum; nondum res ipsa ad eius modi praesidia viros bonos compellebat.'

36 Cf. HARRIES, J. Cicero and the Jurists. From Citizens'Law to the Lawful State. London: Duckworth, 2006, p. 227 ff.; LINTOTT, A. Cicero as Evidence - a Historians Companion. Oxford: Oxford University Press, 2008, p. 29, nt. 76.

37 Due to the fact that in the year $56 \mathrm{BC}$ Clodius was an aedile (it is known from the letter of Cicero - $Q F$ 2, 2, 2: De aedificatione tua Cyrum urgere non cesso: spero eum in officio fore; sed omnia sunt tardiora propter furiosae aedilitatis exspectationem; nam comitia sine mora futura videntur: edicta sunt in a.d. XI. Kal. Febr.), it can be assumed that the riots caused by him were part of his election campaign. 
Sestius fell victim to when he tried to make obnuntiatio. ${ }^{38}$ This institution enabled the blocking of the activities of popular assemblies by a magistrate or an augur, if he referred to unfavourable signs. Such a possibility was provided by the lex Aelia Fufia, ${ }^{39}$ enacted in $154 \mathrm{BC}$. But to make obnuntiatio, the person conducting the observations must be present on the spot of the gathering. And on this spot Sestius was assaulted by Clodius' men. According to Cicero, the tribune came alive out of this oppression only because the attackers thought they had already killed him. ${ }^{40}$ It was after this incident that Sestius hired armed security. From this succession of events the orator made the conclusion that it were the activities of Clodius that made Sestius to use vis. ${ }^{41}$ And this forced use of violence was completely justified and legal, according to the orator. Even more - Sestius' use of violence was pro re publica, contrary to the destructive acts of Clodius.

It seems that during the pro Sestio speech Cicero used the word vis in its neutral meaning also. For him the application of law instead of force was a sign of progress:

Cic. Sest. 92: Atque inter hanc vitam perpolitam humanitate et illam immanem nihil tam interest quam ius atque vis. Horum utro uti nolumus, altero est utendum. vim volumus exstingui, ius valeat necesse est, id est iudicia, quibus omne ius continetur; iudicia displicent aut nulla sunt, vis dominetur necesse est.

The orator emphasized that one of the two means was always used to maintain order: either force or law. In his opinion, it is impossible to apply both at the same time because they are mutually exclusive. Whoever does not want to act by law must resort to strength, and vice versa. Following the law means submitting to the state apparatus that operates within the law and applies it. The application of law is a sign of civilized societies, the use of force/violence is characteristic for savage societies.

It seems that gradually, during the speech, the sense of the word changed which is visible in the abovementioned fragment too. It starts with vis in its neutral significance and evolves to the meaning of simple violence. It would not be unusual for a skilled orator to introduce the change subtly. His aim was, after all, to show that Publius Sestius was innocent of any punishable form of vis. It might even be that the same word used at the end of this fragment already has a negative meaning - when employed in the opposition to the administration of law, vis means violence, something of illegal character, not just force. But the accused used the force, not violence - Sestius was absolved.

Not every use of violence, even an obvious one, was penalized by law, then. As was said before, the leges issued at the end of the Republic and the beginning of the Principate stated very clearly when it was punished. Bearing all this in mind, let us consider some cases of vis forbidden by the law, the ones that are not clearly associated with the use of violence.

\footnotetext{
38 Cf. GRUEN, op. cit., p. 255 ff.; BEARD, M. - NORTH, J. - PRICE, S. Religions of Rome, vol. I: A History. New York, 2009, p. 110 ff.; LINTOTT, Violence in Republican Rome, p. 71; LOSKA, E. Uwagi na temat procedury obnuntiatio. Zeszyty Prawnicze, 2011, 11, 1, p. $212 \mathrm{ff}$.

39 ROTONDI, op. cit., p. $288 \mathrm{ff}$.

40 Cic. Sest. 79.

41 Cic. Sest. 88.
} 


\section{Lex Iulia de vi publica}

In the title of the Digest dedicated to the commentary of the lex Iulia de vi publica it is preserved that under this bill a legally responsible is a person:

D. 48, 6, 10 pr. (Ulp. 68 ad ed.): Qui dolo malo fecerit, quo minus iudicia tuto exerceantur aut iudices ut oportet iudicent vel is, qui potestatem imperiumve habebit, quam ei ius erit, decernat imperet faciat. (...) item qui cum telo dolo malo in contione fuerit aut ubi iudicium publice exercebitur (...).

Therefore, the person liable under this statute was anyone who maliciously obstructed safe exercise of justice, held back the judges from the proper giving of verdict, hindered any magistrate with imperium or potestas from giving decrees, orders or doing what their right to do was. The person held liable was also someone who with ill intent and armed with weapon entered an informal gathering or a place where a criminal trial was being conducted.

It can be said that vis was publica when was directed against the community or applied by the official.

\section{Lex Cornelia de sicariis and veneficis}

Some forms of perverting the course of justice were penalized also earlier in the sullan lex Cornelia de sicariis and veneficis:

D. 48, 8, 1 pr. (Marci. 14 inst.): Lege Cornelia de sicariis et veneficis tenetur, qui hominem occiderit: cuiusve dolo malo incendium factum erit: quive hominis occidendi furtive faciendi causa cum telo ambulaverit: quive, cum magistratus esset publicove iudicio praeesset, operam dedisset, quo quis falsum indicium profiteretur, ut quis innocens conveniretur condemnaretur.

Under this law anyone who killed a man, maliciously set the fire, walked about with a weapon with intention of theft or murder was held liable. Anyone who permitted giving false evidence/deposition leading to the sentencing of an innocent person while holding an office or presiding a criminal trial was legally responsible. The words indicium profiteor can be literally translated as "to volunteer information against an accomplice", but in my opinion, it could apply to every kind of false evidence against anyone innocent. Later this last case should have been called vis publica - the abuse of office by the magistrate, prohibited by Augustus. ${ }^{42}$ According to the lex Iulia de vi publica, it was forbidden to anyone to obstruct the trial. To anyone, and thus also to the president of the tribunal.

Very interesting point was made by D. Nörr. It concerned the word occidere. Referring to the first chapter of the lex Aquilia, he stated that in classical Latin occidere means every type of killing, either direct or indirect. ${ }^{43}$ The subject of the lex Aquilia were only the cases when there was a direct connection between the deed of the wrongdoer and the effect.

42 See HARRIES, Law and Crime in the Roman World, p. 107 and 110. The author puts the distinction vis publica/vis privata in 2nd century only.

43 NÖRR, D. Causam Mortis Praebere. In: The Legal Mind: Essays for Tony Honore. Oxford: Oxford University Press, 1986, p. 204. 
But from the times of Plautus the meaning started to develop and to expand to the wider one. This would mean, and this is important to me, that in the times of Sulla the sense of this word was already a broader one-occidere could mean also an indirect killing. This occurrence was known to the oratory and rhetoric of the late Republic, which was later called by the jurist Celsus causam mortis praestare - D. 9, 2, 7, 6). ${ }^{44}$ It might be that this difference was also made by the lex Cornelia. That would mean that the statute of Sulla punished three types of deeds: direct slaughter (or the danger of death, as in case of the fire), causing death in an indirect manner and also the actions that were legal themselves, but punishable if taken hominis necandi causa.

It seems then that every case of killing, even so called "judicial homicide" could be qualified as punishable under this statute. This thought can be justified, as Marcianus further wrote:

D. 48, 8, 1, 1 (Marci. 14 inst.): Praeterea tenetur, qui hominis necandi causa venenum confecerit dederit: quive falsum testimonium dolo malo dixerit, quo quis publico iudicio rei capitalis damnaretur. ${ }^{45}$

Moreover, anyone who produced or handed in poison with the intention to kill or gave maliciously and intentionally false evidence wanting someone to be sentenced in a criminal trial for a capital offence was also liable under the lex Cornelia de sicariis and veneficis.

The last two fragments complement each other perfectly - a person who gives false testimony in a criminal trial as well as an official who submits or even arranges these testimonies are both liable. This means, that the false evidence was regarded as a kind of public violence, punishable under the lex Cornelia de sicariis and later also under the lex Iulia de vi publica. The magistrate seemed to be always responsible, the witness was responsible only if they had acted dolo malo. This simple fact allows me to think that during the Principate those offences could be prosecuted in the questio de vi.

These cases ideally coincide with the statement of Cicero - where there is no law, there is violence. False testimonies made it impossible for officials and tribunals to apply the law because they led to wrong judgment and to the death of an innocent person. Therefore those cases can be considered a form of violence. And as such they should be punished. It should also be underlined that using any kind of violence in a Roman court was unacceptable. It should be the place where the justice is administered - justice that exclude the violence. Obviously, Cicero's speech was intended to defend Sestius against the charge of violence, i.e. physical violence. I do not mean to suggest that this point of view must be taken into consideration in every criminal case. But this dichotomy - law or violence - seems to be typical for the behaviour of the Romans at the end of the Republic/beginning of the Principate.

44 NÖRR, Causam Mortis Praebere, p. 216-217.

45 Cf. Coll. 1, 2, 1: PAULUS quoque libro quinto sententiarum sub titulo ad legem Corneliam de sicariis et veneficis dicit: Lex Cornelia poenam deportationis infligit ei, qui hominem occiderit eiusque rei causa furtive faciendi cum telo fuerit, et qui venenum hominis necandi causa habuerit vendiderit paraverit, falsumve testimonium dixerit quo quis periret, mortisve causam praestiterit. $=$ Coll. 8, 4, 1; = PS 5, 23, 1 . 


\section{Calumny}

It seems likely, therefore, that a submission and acceptance of false testimony can be considered as a type of violence. It is even more probable to think so of the false accusation, that is calumny.

The calumny was first recognized as a crime by the lex Remmia de calumniatoribus of the year 81 BC. ${ }^{46}$ The need for the specific lex concerned with this misdeed resulted from the establishment of the quaestiones perpetuae in the times of Sulla, so this dating is very probable.

Calumny in criminal proceedings was also one of the subjects of SC Turpillianum from 61:

D. 48, 16, 1, 1 (Marci. 1.s. ad sc turp.): Calumniari est falsa crimina intendere (...) 2. Calumniatoribus poena lege Remmia irrogatur.

The jurist stressed that to calumniate means to accuse of a false crime. If calumny was proven, the prosecutor was punished with the penalty from the lex Remmia, so probably became infamous. ${ }^{47}$ It resulted, among other things, in the impossibility of future prosecuting (unless the victim of the crime was the accuser himself or the people closest to him). However, if we assume that calumny could be seen as a manifestation of violence, it might be that calumniator could be put on trial also because he was using vis. It seems important, as infamy does not constitute an adequate penalty for attempted murder - and attempted murder it is if the false accusation resulted in the capital trial.

Marcianus further gives grounds for considering the unproven accusation a crime in itself:

D. 48, 16, 1, 3 (Marci. 1.s. ad sc turp.): Sed non utique qui non probat quod intendit protinus calumniari videtur: nam eius rei inquisitio arbitrio cognoscentis committitur, qui reo absoluto de accusatoris incipit consilio quaerere, qua mente ductus ad accusationem processit, et si quidem iustum eius errorem reppererit, absolvit eum, si vero in evidenti calumnia eum deprehenderit, legitimam poenam ei irrogat. 4. Quorum alterutrum ipsis verbis pronuntiationis manifestatur. Nam si quidem ita pronuntiaverit "non probasti", pepercit ei: sin autem pronuntiavit "calumniatus es”, condemnavit eum. (...).

According to the jurist's words, the accuser's intention is the most important to recognize an unproven charge for calumny. If the president of the court considers the accuser's mistake as legitimate, he releases him from liability. If, however, he catches the accuser obviously harassing someone, he punishes him with penalty provided by law. The decision of the criminal court's presiding official is already evident in the way in which he announces the verdict. He may say "You did not prove" (and then the matter ended) or "You accused falsely" (and then the prosecutor was punished). This means that the

46 CENTOLA, D. A. Il crimen calumniae. Napoli: Editoriale Scientifica, 1999, p. 24. The first mention of calumnia in the legal act was the requirement of the iusiurandum calumniae by the prosecutor in the lex repetundae Tabulae Bembinae from the times of Gaius Gracchus - Ibidem, p. 11.

47 Cic. Rosc. Am. 55; cfr. CAMIÑAS, J. D. La lex Remmia de calumniatoribus. Santiago de Compostela: Universidad de Santiago de Compostela, 1984, p. 117 ff. 
consequences of making a false accusation were borne by the prosecutor who was well aware of the falsehood of the allegations.

During the Republic, the calumniator was probably prosecuted before the same jurors as the falsely accused, ${ }^{48}$ at the conclusion of the same trial. After the enacting of $S C$ Turpillianum, calumny was punished in an extra ordinem procedure, as Paulus informed:

D. 48, 16, 3 (Paul. 1 sent.): Et in privatis et in extraordinariis criminibus publicis iudiciis omnes calumniosi extra ordinem pro qualitate admissi plectuntur.

Paulus wrote that a calumniator, both in private and in criminal cases, was punished according to the extent of his crime. So the extra ordinem procedure allowed to adjust the punishment for the calumniator depending on the penalty he expected for the person he wrongly accused. And from this moment searching the appropriate punishment for calumniator in the leges de vi was no longer necessary.

\section{Conclusion}

To sum up, there are many forms of violence: physical one, psychological one, direct one, indirect one. Most of them are not legally indifferent. In ancient Rome the law stated what was considered violence and how it was penalized. Violence as the illegal use of physical force could be punished in the criminal court. But as I was trying to present not only this emanation of violence was punishable in the public trial. Calumny as a way of perverting the course of justice can be seen as such too.

48 Asc. in Scaur. 29C. 